\title{
Electrical Inhibition of Identified Anorexigenic POMC Neurons by Orexin/Hypocretin
}

\author{
Xiaosong Ma, ${ }^{1}$ Lejla Zubcevic, ${ }^{1}$ Jens C. Brüning, ${ }^{2}$ Frances M. Ashcroft, ${ }^{1}$ and Denis Burdakov ${ }^{3}$ \\ ${ }^{1}$ University Laboratory of Physiology, Oxford OX1 3PT, United Kingdom, ${ }^{2}$ Institute for Genetics, Department of Mouse Genetics and Metabolism, and \\ Center of Molecular Medicine, University of Cologne, 50674 Köln, Germany, and ${ }^{3}$ Department of Pharmacology, University of Cambridge, Cambridge CB2 \\ 1PD, United Kingdom
}

Proopiomelanocortin (POMC) neurons of the hypothalamic arcuate nucleus (ARC) suppress appetite, and lack of POMC-derived peptides or electrical silencing of POMC neurons causes obesity. ARC POMC neurons are surrounded by nerve terminals containing the wakefulness-promoting peptides orexins/hypocretins, but whether orexin affects their electrical activity has not been tested directly. Here we identify living ARC POMC cells in mouse brain slices by targeted expression of green fluorescent protein. Using whole-cell patch-clamp recordings, we show that orexin suppresses the spontaneous action potential firing of these neurons. Orexin-induced inhibition involves membrane hyperpolarization, a decreased excitatory synaptic drive, and an increased frequency of GABAergic inputs. Our results suggest a reduction in the electrical activity of ARC POMC neurons, which is mediated by changes in presynaptic inputs, contributes to the appetite-enhancing action of orexins.

Key words: POMC neurons; orexin; hypocretin; appetite; obesity; arcuate nucleus

\section{Introduction}

Proopiomelanocortin (POMC)-containing neurons of the hypothalamic arcuate nucleus (ARC) are important regulators of body energy balance, acting to reduce appetite and body weight (Schwartz et al., 2000; Cone, 2005). They are the source of transmitters that suppress feeding and/or stimulate energy expenditure, such as $\beta$-endorphin, $\alpha$-MSH, and CART (cocaine and amphetamine regulated transcript) peptide (Elias et al., 1998; Cone, 2005). Transmitter release at projection targets such as the hypothalamic paraventricular nucleus and sympathetic areas of the spinal cord is thought to underlie the anorexigenic effects of POMC cells (Elias et al., 1998; Cowley et al., 1999). This release is controlled by the electrical activity of POMC cells, because electrical silencing of these neurons causes obesity (Plum et al., 2006). Ablation of POMC neurons, loss of POMC-derived transmitters, or lack of excitatory leptin signaling in POMC cells also produces obesity (Yaswen et al., 1999; Balthasar et al., 2004; Gropp et al., 2005).

ARC POMC cells integrate diverse peripheral and central signals to match transmitter release to the body's energy status (Cone, 2005). One of their major inputs comes from lateral hypothalamic neurons containing the peptide transmitters orexins/ hypocretins (de Lecea et al., 1998; Sakurai et al., 1998). Orexins are critical for sustaining normal wakefulness in mammals, and loss of orexins or orexin type-2 receptors leads to narcolepsy (Chemelli et al., 1999; Lin et al., 1999). They also stimulate appe-

\footnotetext{
Received Aug. 18, 2006; revised Jan. 3, 2007; accepted Jan. 3, 2007.

This work was supported by the Wellcome Trust Integrative Physiology Initiative in Metabolic Disease. F.M.A. is a Royal Society Research Professor. D.B. is a Royal Society Dorothy Hodgkin Fellow. X.M. is a Wellcome Training fellow. We thank B. Lowell and J. Elmquist for providing POMC-Cre transgenic mice.

Correspondence should be addressed to Prof. Frances M. Ashcroft, University Laboratory of Physiology, Parks Road, 0xford 0X13PT, UK. E-mail: frances.ashroft@physiol.ox.ac.uk.

DOI:10.1523/JNEUROSCI.3583-06.2007

Copyright $\odot 2007$ Society for Neuroscience $\quad$ 0270-6474/07/271529-05\$15.00/0
}

tite and control brain reward systems (Sakurai et al., 1998; Harris et al., 2005; Borgland et al., 2006). In mice, loss of orexins prevents fasting-induced wakefulness and locomotor activity (Yamanaka et al., 2003; Mieda et al., 2004) and can cause abnormalities in body-weight regulation (Hara et al., 2001). The activity of orexin cells is highest during active wakefulness and lowest during slow-wave sleep (Lee et al., 2005; Mileykovskiy et al., 2005) and is regulated by numerous central inputs (Sakurai et al., 2005), as well as by circulating signals of body energy status, such as leptin and glucose (Yamanaka et al., 2003; Burdakov et al., 2006). This suggests that the activity of orexin neurons may ensure that food seeking is accompanied by alertness and occurs at environmentally appropriate times (Willie et al., 2001; Sakurai, 2003; Scott et al., 2006).

Both cell bodies and axon terminals in the ARC express orexin receptors (Guan et al., 2002). ARC POMC cells are surrounded by orexin-containing nerve terminals (Guan et al., 2001; Muroya et al., 2004), and there is strong orexin receptor-1 immunoreactivity in and around ARC POMC cells (Backberg et al., 2002; Suzuki et al., 2002). Microinjection of orexin into the ARC stimulates feeding (Muroya et al., 2004), and orexin reduces intracellular $\mathrm{Ca}^{2+}$ levels in isolated POMC neurons (Muroya et al., 2004), suggesting that orexin may suppress the electrical activity of the anorexigenic POMC cells. However, this possibility remains to be tested directly. Here, we identify ARC POMC cells in mouse brain slices by targeted expression of enhanced green fluorescent protein (eGFP) and study their electrical responses to orexin. We show that orexin decreases the electrical activity of POMC cells, primarily by modulating synaptic inputs.

\section{Materials and Methods}

Generation of POMC-eGFP transgenic mice. The POMC-eGFP mice were created using the Cre-lox system. The generation and validation of 
the POMC-eGFP mouse model has been described in detail previously (Balthasar et al., 2004; Plum et al., 2006).

Electrophysiology. Coronal brain slices $(250-300 \mu \mathrm{m})$ containing the ARC were prepared from 10- to 16-d-old POMC-eGFP mice. After at least a $15 \mathrm{~min}$ recovery at $35^{\circ} \mathrm{C}$ in artificial CSF (ACSF) gassed with $95 \%$ $\mathrm{O}_{2}$ and $5 \% \mathrm{CO}_{2}$, brain slices were transferred to a recording chamber and perfused continuously at 2-4 $\mathrm{ml} / \mathrm{min}$ with gassed ACSF using an ISMATEC (Glattbrugg, Switzerland) solution pump. The ACSF contained (in mM) $125 \mathrm{NaCl}, 21 \mathrm{NaHCO}_{3}, 2.5 \mathrm{KCl}, 1.2 \mathrm{NaH}_{2} \mathrm{PO}_{4}, 2 \mathrm{CaCl}_{2}, 2 \mathrm{MgCl}_{2}$, 10 HEPES, pH 7.4, and 5 glucose.

Brain slices were viewed with a Zeiss (Weleyn Garden City, UK) Axioskop microscope fitted with fluorescence and infrared differential interference contrast (IR-DIC) systems. Fluorescent POMC-eGFP neurons were identified by epifluorescence and patched under IR-DIC optics. Whole-cell current-clamp and voltage-clamp recordings were made using an EPC-9 patch-clamp amplifier, as described previously (Plum et al., 2006; Burdakov and Ashcroft, 2002). Patch pipettes had resistances of 3-5 $\mathrm{M} \Omega$ when filled with an internal solution. Resting potentials of firing neurons were determined from slow time-scale recordings on which a clear basal line was evident; this baseline was taken as the resting potential (Plum et al., 2006) (see also Fig. 2C). For measurement of postsynaptic currents (PSCs), cells were voltage clamped at -60 $\mathrm{mV}$ and sampled at a frequency of $20 \mathrm{kHz}$. To calculate PSC frequency, events were recorded continuously for 5-10 $\mathrm{min}$ in each solution. They were analyzed off-line for a continuous stretch of recording of $1 \mathrm{~min}$ (or more) duration by displaying and counting events in successive $3 \mathrm{~s}$ intervals (to facilitate accurate counting). The number of events was divided by the recording length (in seconds) to obtain the PSC frequency in hertz. The two-sided Kolmogorov-Smirnov analysis of PSC intervals (see Fig. $3 D-F$ ) was performed using MATLAB 6.5 software (The MathWorks, Natick, MA). In all histograms, data are shown as mean \pm SEM.

For most experiments, patch pipettes were filled with an internal solution containing the following (in $\mathrm{mm}$ ): $128 \mathrm{~K}$-gluconate, $10 \mathrm{KCl}, 10$ HEPES, pH 7.3 (adjusted with $\mathrm{KOH}$ ), 0.1 EGTA, $2 \mathrm{MgCl}_{2}, 0.3 \mathrm{Na}-\mathrm{GTP}$, and $3 \mathrm{~K}_{2}$-ATP. For measurement of PSCs, patch pipettes were instead filled with (in mM) $140 \mathrm{KCl}, 10 \mathrm{HEPES}, 0.1 \mathrm{EGTA}, 5 \mathrm{MgCl}_{2}, 0.3 \mathrm{Na}-\mathrm{GTP}$, and $5 \mathrm{~K}_{2}$-ATP, pH 7.3 adjusted with $\mathrm{KOH}$. The external solution was ACSF in all experiments. Orexin-A (subsequently abbreviated orexin), tetrodotoxin, 6-cyano-7-nitroquinoxaline-2.3-dione disodium salt (CNQX), D(-)-2-amino-5-phosphonopentanoic acid (D-AP-5), 3-aminopropane diethoxymethyl phosphinic acid (CGP 35348), bicuculline, and picrotoxin were added to the bath solution where indicated. All drugs were from Sigma (Poole, UK), except bicuculline and CGP 35348 (Tocris, Bristol, UK). Experiments were performed at $22-25^{\circ} \mathrm{C}$.

\section{Results}

Identification of ARC POMC neurons in mouse brain slices POMC neurons are difficult to identify in the ARC because they have few characteristic anatomical features and are intermixed with several other types of ARC cells. To overcome this problem, we used transgenic mice that selectively express eGFP in POMC neurons (Plum et al., 2006). Whole-cell patch-clamp recordings from POMC-eGFP neurons in ARC brain slices revealed that they fire spontaneously (Fig. $1 A, B$ ) with a frequency of between 0.3 and $8.1 \mathrm{~Hz}$ (mean, $2.5 \pm 0.3 \mathrm{~Hz} ; n=50$ ). These values are similar to those reported previously for identified POMC cells (Ghamari-Langroudi et al., 2005).

We and others have previously identified at least three subtypes of ARC neurons that have distinct electrophysiological properties (Burdakov and Ashcroft, 2002; Fioramonti et al., 2004). To compare these electrophysiological fingerprints with those of identified POMC neurons, we applied the same current injection protocol (Burdakov and Ashcroft, 2002) to POMCeGFP cells (Fig. 1A,B). Eight of 12 POMC-eGFP neurons exhibited little or no postinhibitory rebound potential or changes in firing after a hyperpolarizing current pulse (Fig. $1 A$ ), which is similar to "type-A" ARC neurons in our previous classification
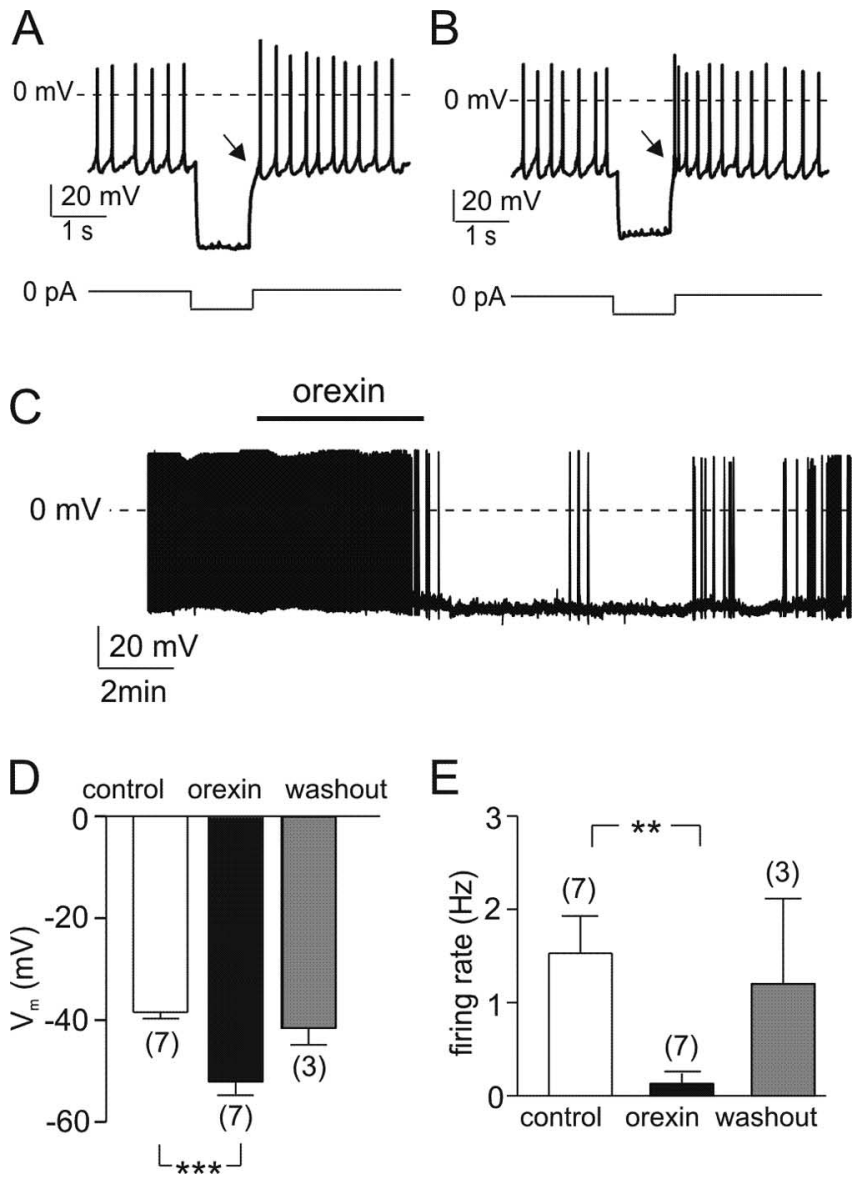

Figure 1. Effects of orexin on the membrane potential of POMC neurons. $A, B$, Responses of POMC neurons to a hyperpolarizing current injection. The cells either exhibited no rebound potential $(\boldsymbol{A}$, arrowed) or a rebound depolarization and transient acceleration of firing $(\boldsymbol{B}$, arrowed). The current-clamp protocol is shown schematically beneath the traces. $C$, Representative membrane potential recording from an identified POMC neuron. Orexin (100 nm; applied during the bar) hyperpolarized the neuron and reduced the firing rate. $D$, Mean membrane potential before, during, and after exposure to $100 \mathrm{~nm}$ oxrexin. The effects of orexin were reversible in only three of seven cells. ${ }^{* *} p<0.001 . \boldsymbol{E}$, Mean action potential frequency before, during, and after exposure to $100 \mathrm{~nm}$ orexin. The effects of orexin were reversed in only three of seven cells. ${ }^{* *} p<0.01$. The numbers in parentheses indicate the number of cells.

(Burdakov and Ashcroft, 2002). The other four POMC-eGFP neurons displayed a postinhibitory rebound depolarization accompanied by an acceleration of spike firing (Fig. $1 B$ ): this resembles "type-B" ARC neurons (Burdakov and Ashcroft, 2002). However, we also found the same biophysical fingerprints in other nonfluorescent neurons from the ARC and the neighboring ventromedial nucleus $(n=20)$, suggesting that they are not unique to POMC cells. We subsequently refer to POMC-eGFP neurons simply as POMC neurons.

\section{Effects of orexin on membrane potential and electrical activity}

To investigate the effects of orexin on the electrical activity of POMC neurons, we first performed whole-cell current-clamp recordings with zero holding current (Fig. 1C). Bath application of $100 \mathrm{~nm}$ orexin either significantly reduced or abolished the spontaneous action potentials of POMC neurons $(n=7)$ (Fig. $1 C, E)$. This inhibitory effect was associated with a small but significant membrane hyperpolarization (Fig. 1C,D). The electrical effects of orexin were fully or partially reversible in some POMC 
A tetrodotoxin
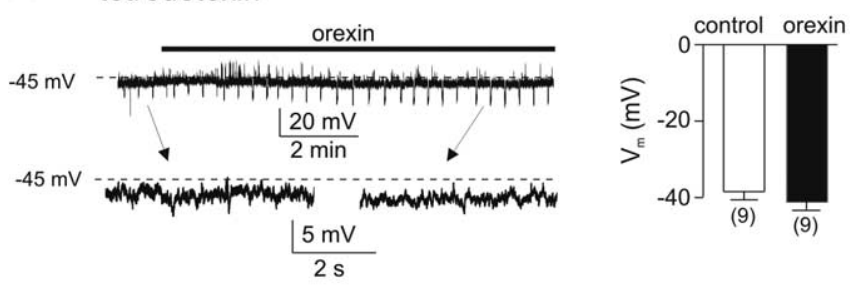

B DAP5+CNQX+picrotoxin

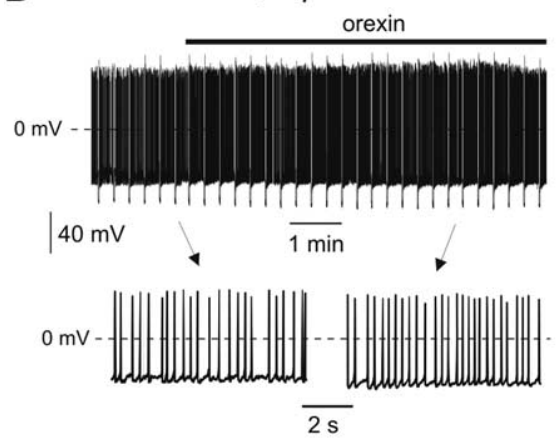

C picrotoxin
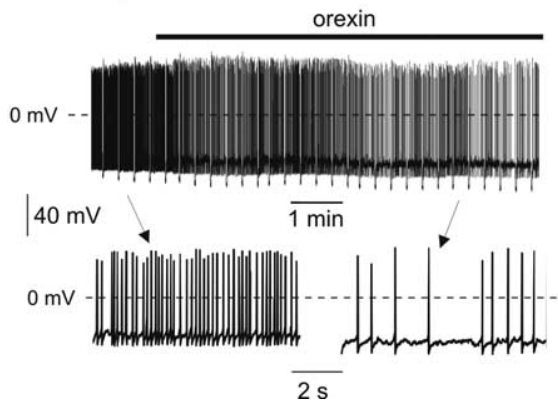

$2 \mathrm{~s}$

Figure 2. Effects of orexin on electrical activity in the presence of inhibitors of synaptic communication. Left panels, Representative membrane potential recordings. Top traces show complete recordings on a slow time scale. Orexin (100 nm) was applied during the bar. Downward voltage deflections are caused by periodic injections of hyperpolarizing current, which were applied to monitor membrane resistance (no significant changes were observed). Bottom traces show expanded sections of the top traces (as indicated) at a higher time resolution. The right panels show the mean membrane potential $(\boldsymbol{A})$ or firing rate $(\boldsymbol{B}, \boldsymbol{C})$ in the presence and absence of orexin. Experiments were performed in the continuous presence of $1 \mu \mathrm{m}$ tetrodotoxin $(\boldsymbol{A}), 50 \mu \mathrm{m}$ D-AP-5 plus $10 \mu \mathrm{m}$ CNQX plus $100 \mu \mathrm{m}$ picrotoxin $(\boldsymbol{B})$, or $100 \mu \mathrm{m}$ picrotoxin $(\boldsymbol{C})$. ${ }^{*} p<0.05$. The numbers in parentheses indicate the number of cells.

cells $(n=3$ of 7 ) (Fig. $1 C-E)$, but in other cells, no reversal was seen within $20 \min (n=4)$.

We next repeated these experiments in the presence of $1 \mu \mathrm{M}$ tetrodotoxin, to block $\mathrm{Na}^{+}$-dependent action potentials. Under these conditions, $100 \mathrm{~nm}$ orexin no longer had a significant effect on the membrane potential of POMC neurons $(n=7)$ (Fig. $2 A)$. This suggests that changes in voltage-activated currents, or action potential-mediated presynaptic inputs, may be responsible for the observed effects of orexin on the firing and membrane potential of POMC neurons.

\section{Effects of orexin on membrane potential in the presence of synaptic blockers}

To distinguish between these two possibilities, we next tested the effect of blocking synaptic inputs to POMC cells. Most synaptic activity in hypothalamic circuits is thought to be mediated by release of GABA or glutamate (van den Pol et al., 1998). We therefore used CNQX $(10 \mu \mathrm{M})$ to block AMPA receptors, D-AP-5
(50 $\mu \mathrm{M})$ to block NMDA receptors, and either picrotoxin (100 $\mu \mathrm{M})$ or bicuculline $(20 \mu \mathrm{M})$ to block $\mathrm{GABA}_{\mathrm{A}}$ receptors. When all three receptor types were blocked, orexin was without significant effect on either the membrane potential or the firing frequency of POMC cells $(n=5)$ (Fig. $2 B)$. This suggests that changes in action potential-dependent release of GABA and/or glutamate are primarily responsible for the effects of orexin on the electrical activity of POMC cells.

To determine the relative contributions of the two transmitter systems (glutamate vs GABA), we examined the effects of orexin in the presence of picrotoxin alone. Picrotoxin $(100 \mu \mathrm{M})$ reduced the inhibitory effects of orexin on firing of POMC cells by $\sim 45 \%$ (Fig. 2C). This suggests that orexin-induced inhibition of POMC neurons involves both potentiation of the inhibitory GABAergic inputs and suppression of the excitatory glutamatergic drive.

\section{Effects of orexin on synaptic currents}

To visualize the effects of orexin on synaptic currents directly, we performed whole-cell voltage-clamp recordings on identified POMC cells. We used chloride as the main intracellular anion and a holding potential of $-60 \mathrm{mV}$; under these conditions, both glutamatergic and GABAergic currents are inward (Fig. 3A). Application of $100 \mathrm{nM}$ orexin reduced the total frequency of PSCs by $\sim 40 \%$ (Fig. $3 A, B)$. However, when glutamatergic PSCs were blocked with DAP-5 and CNQX, the frequency of the remaining synaptic currents was higher in the presence of orexin than in its absence (Fig. $3 A, C$ ). The D-AP-5/CNQX-resistant synaptic currents were completely blocked by bicuculline or picrotoxin, confirming that they are mediated by $\mathrm{GABA}_{\mathrm{A}}$ receptor $\mathrm{Cl}^{-}$channels (Fig. $3 A$, bottom traces). Orexin decreased the frequency of GABAergic PSCs but reduced the frequency of glutamatergic PSCs (Fig. 3C). Kolmogorov-Smirnov analyses of inter-PSC time intervals (Fig. $3 D-F$ ) reinforced the conclusion that orexin mediates its effects on POMC cell electrical activity by decreasing the frequency of glutamatergic PSCs and increasing the frequency of GABAergic PSCs.

These results are consistent with our current-clamp data (Fig. $2 B, C$ ) and confirm that orexin mediates its effects on POMC cell electrical activity via changes in both GABAergic and glutamatergic PSCs. Of note, orexin significantly reduced the occurrence of glutamatergic PSCs when $\mathrm{GABA}_{\mathrm{B}}$ receptors were blocked with CGP 35348 (Fig. $3 E$ ), indicating that inhibitory $\mathrm{GABA}_{\mathrm{B}}$ receptors are not required for suppression of glutamatergic inputs by orexin.

\section{Discussion}

In this study, we show that orexin suppresses action potential firing and hyperpolarizes the membrane potential of ARC POMC neurons (Fig. 1). These effects appear to be mainly attributable to orexin-induced modulation of synaptic inputs of POMC cells, because they are abolished in the presence of tetrodotoxin (Fig. $2 A$ ) or blockers of glutamatergic and GABAergic synaptic transmission (Fig. 2 B). We present evidence that orexin-induced electrical inhibition involves changes in the balance between synaptic excitation and inhibition. Specifically, we observed that orexin induced a reduction in the frequency of excitatory glutamatergic inputs sensitive to D-AP-5/CNQX but an increase in the frequency of inhibitory GABAergic inputs sensitive to bicuculline or pictrotoxin (Fig. 3C, E, F).

We speculate that the increased GABAergic drive may originate from local GABAergic interneurons and/or ARC neurons containing both GABA and NPY/AgRP (agouti-related protein), which are known to be electrically exited by orexin (Burdakov et al., 2003; van den Top et al., 2004). However, we cannot exclude the possibility that the orexin-modulated GABA and glutamate 
inputs originate from neurons located elsewhere in our coronal slice preparation.

In our experiments, the presynaptic action of orexin on POMC neurons appeared slower in both onset and washout than the direct postsynaptic action of the peptide on ARC GABAergic neurons [compare Fig. $1 C$ with responses described by Burdakov et al. (2003)]. This is probably because at least some of the presynaptic neurons on which orexin acts are likely to lie deep within the slice, where access is slower and more restricted, whereas when orexin acts directly on the recorded neuron, it only needs to reach the surface of the slice, where the recorded neuron is located (Burdakov et al., 2003).

It is noteworthy that in ARC POMC neurons, the appetite-promoting peptide ghrelin also increases IPSCs, whereas the anorexinogen leptin decreases the IPSC frequency (Pinto et al., 2004; Cone, 2005). Modulation of synaptic inputs to POMC neurons may thus be a general way for body weight-regulating compounds to modulate the activity of ARC POMC cells.

Muroya et al. (2004) showed that orexin reduced the intracellular $\mathrm{Ca}^{2+}$ concentration of isolated POMC neurons, suggesting that orexin directly interacts with POMC neurons. In contrast, in our experiments, the effects of orexin on the firing rate of POMC cells appeared to be primarily "indirect," via modulation of synaptic inputs. These observations are not necessarily contradictory because it is possible to alter cytosolic $\mathrm{Ca}^{2+}$ levels without major effects on the resting membrane potential of a cell. Presumably, it is also possible that some presynaptic terminals may remain attached to the membranes of isolated POMC neurons and that orexin could modulate the release of glutamate and GABA from these terminals. Finally, it cannot be ruled out that orexin directly modulates ion channels expressed in POMC neurons, but that these effects are too small to affect the membrane potential in our studies.

Orexin receptor immunoreactivity was observed on and around ARC POMC neurons (Backberg et al., 2002; Suzuki et al., 2002), but it remains to be determined what type of orexin receptor is responsible for the electrical effects described here. Unfortunately, we could not readily obtain a dose-response relationship for the effects of orexin in our preparation. Orexin receptor knock-out mice (Willie et al., 2003) may be a better tool for distinguishing which type of orexin receptor is responsible.

Orexin-containing terminals are found on and around ARC POMC neurons
A
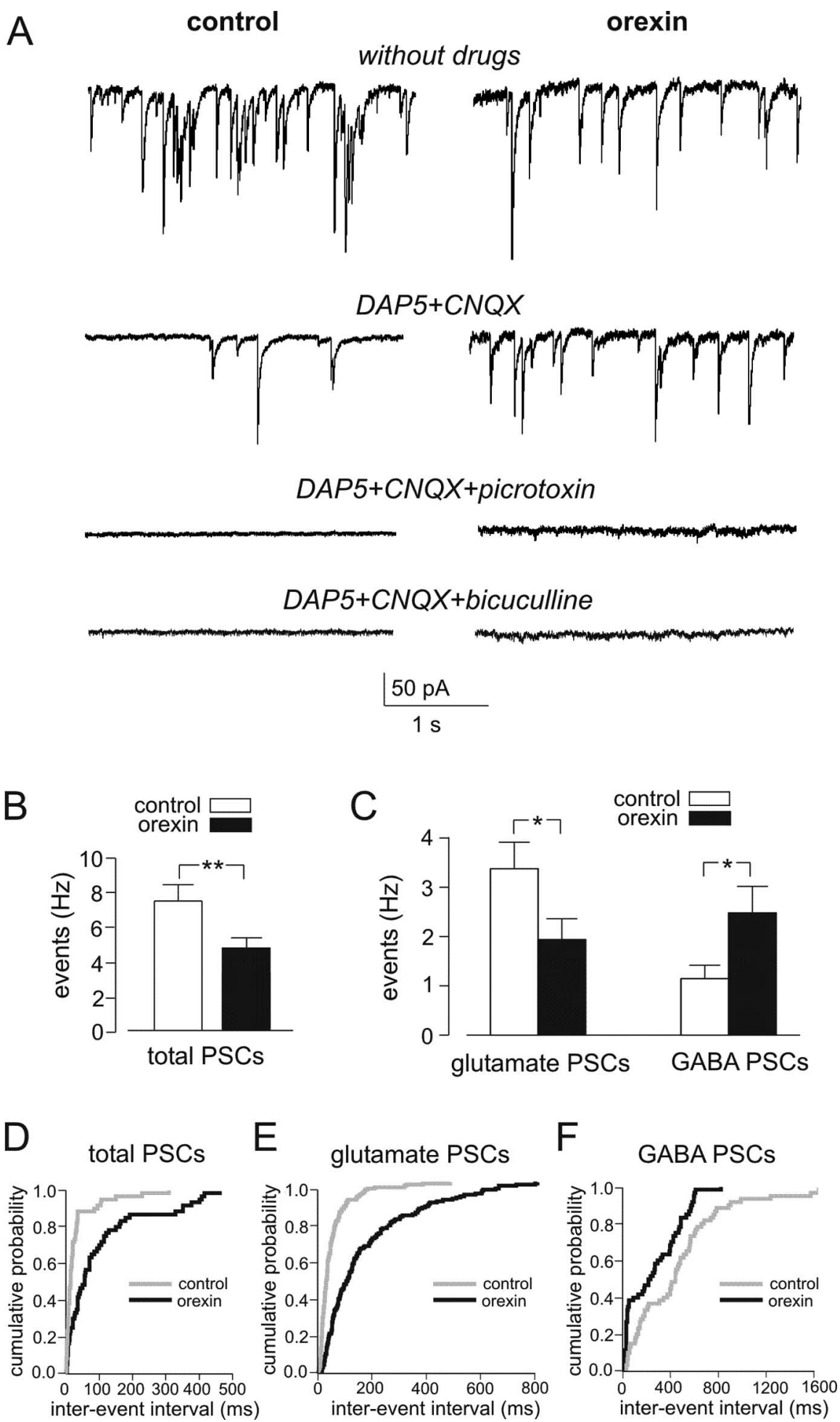

Figure 3. Effects of orexin on spontaneous glutametergic and GABAergic inputs. $\boldsymbol{A}$, Representative recordings of PSCs at -60 $\mathrm{mV}$ before (left, control) and after (right, orexin) the addition of $100 \mathrm{~nm}$ orexin to the external solution. Top traces, No additions. Middle traces, In the presence of $50 \mu \mathrm{m}$ D-AP-5 plus $10 \mu \mathrm{m}$ CNQX. Bottom traces, In the presence of $100 \mu \mathrm{m}$ picrotoxin (or $20 \mu \mathrm{m}$ bicuculline) plus $50 \mu \mathrm{m}$ D-AP-5 plus $10 \mu \mathrm{M}$ CNQX. B, Mean PSC frequency before and after exposure to $100 \mathrm{~nm}$ orexin. ${ }^{* *} p<0.01$. C, Mean glutamatergic and GABAergic PSC frequency before and after exposure to $100 \mathrm{~nm}$ orexin. ${ }^{*} p<0.05$. Glutamate PSCs were identified by their sensitivity to D-AP-5/CNQX and GABA PSCs by sensitivity to picrotoxin. $\boldsymbol{D}-\boldsymbol{F}$, Cumulative probability distributions of inter-PSC intervals, showing that orexin significantly increases the intervals between total $(\boldsymbol{D})$ and glutamergic $(\boldsymbol{E})$ PSCs but reduces the intervals between GABAergic PSCS $(\boldsymbol{F})$. Glutamergic PSCS $(\boldsymbol{E})$ were recorded in the presence of $20 \mu \mathrm{m}$ bicuculline and $100 \mu \mathrm{M}$ CGP 35348. Kolmogorov-Smirnov tests indicated significant differences between orexin and control PSC distributions: $p<0.001, k=0.48(\boldsymbol{D}) ; p<0.001, k=0.49(\boldsymbol{E}) ; p<0.01, k=0.3(\boldsymbol{F})$. Data from at least three cells (and $>50$ intervals per cell) were used for each graph. 
(Guan et al., 2001; Muroya et al., 2004), and the release of orexin is highest during active, awake periods (Kiyashchenko et al., 2002). Considering the appetite-suppressing influence of POMC neurons, their electrical inhibition by orexin, described here, may help to ensure that food seeking coincides with periods when the animal is most alert and active. Conversely, during periods of rest and sleep, the reduced release of orexin (Kiyashchenko et al., 2002) may enhance the firing of POMC neurons, suppressing hunger to facilitate the induction and maintenance of sleep states.

\section{References}

Backberg M, Hervieu G, Wilson S, Meister B (2002) Orexin receptor-1 (OXR1) immunoreactivity in chemically identified neurons of the hypothalamus: focus on orexin targets involved in control of food and water intake. Eur J Neurosci 15:315-328.

Balthasar N, Coppari R, McMinn J, Liu SM, Lee CE, Tang V, Kenny CD, McGovern RA, Chua Jr SC, Elmquist JK, Lowell BB (2004) Leptin receptor signaling in POMC neurons is required for normal body weight homeostasis. Neuron 42:983-991.

Borgland SL, Taha SA, Sarti F, Fields HL, Bonci A (2006) Orexin A in the VTA is critical for the induction of synaptic plasticity and behavioral sensitization to cocaine. Neuron 49:589-601.

Burdakov D, Ashcroft FM (2002) Cholecystokinin tunes firing of an electrically distinct subset of arcuate nucleus neurons by activating A-type potassium channels. J Neurosci 22:6380-6387.

Burdakov D, Liss B, Ashcroft FM (2003) Orexin excites GABAergic neurons of the arcuate nucleus by activating the sodium-calcium exchanger. J Neurosci 23:4951-4957.

Burdakov D, Jensen LT, Alexopoulos H, Williams RH, Fearon IM, O'Kelly I, Gerasimenko O, Fugger L, Verkhratsky A (2006) Tandem-pore $\mathrm{K}^{+}$channels mediate inhibition of orexin neurons by glucose. Neuron 50:711-722.

Chemelli RM, Willie JT, Sinton CM, Elmquist JK, Scammell T, Lee C, Richardson JA, Williams SC, Xiong Y, Kisanuki Y, Fitch TE, Nakazato M, Hammer RE, Saper CB, Yanagisawa M (1999) Narcolepsy in orexin knockout mice: molecular genetics of sleep regulation. Cell 98:437-451.

Cone RD (2005) Anatomy and regulation of the central melanocortin system. Nat Neurosci 8:571-578.

Cowley MA, Pronchuk N, Fan W, Dinulescu DM, Colmers WF, Cone RD (1999) Integration of NPY, AGRP, and melanocortin signals in the hypothalamic paraventricular nucleus: evidence of a cellular basis for the adipostat. Neuron 24:155-163.

de Lecea L, Kilduff TS, Peyron C, Gao X, Foye PE, Danielson PE, Fukuhara C, Battenberg EL, Gautvik VT, Bartlett II FS, Frankel WN, van den Pol AN, Bloom FE, Gautvik KM, Sutcliffe JG (1998) The hypocretins: hypothalamus-specific peptides with neuroexcitatory activity. Proc Natl Acad Sci USA 95:322-327.

Elias CF, Lee C, Kelly J, Aschkenasi C, Ahima RS, Couceyro PR, Kuhar MJ, Saper CB, Elmquist JK (1998) Leptin activates hypothalamic CART neurons projecting to the spinal cord. Neuron 21:1375-1385.

Fioramonti X, Lorsignol A, Taupignon A, Penicaud L (2004) A new ATPsensitive $\mathrm{K}+$ channel-independent mechanism is involved in glucoseexcited neurons of mouse arcuate nucleus. Diabetes 53:2767-2775.

Ghamari-Langroudi M, Colmers WF, Cone RD (2005) PYY3-36 inhibits the action potential firing activity of POMC neurons of arcuate nucleus through postsynaptic Y2 receptors. Cell Metab 2:191-199.

Gropp E, Shanabrough M, Borok E, Xu AW, Janoschek R, Buch T, Plum L, Balthasar N, Hampel B, Waisman A, Barsh GS, Horvath TL, Bruning JC (2005) Agouti-related peptide-expressing neurons are mandatory for feeding. Nat Neurosci 8:1289-1291.

Guan JL, Saotome T, Wang QP, Funahashi H, Hori T, Tanaka S, Shioda S (2001) Orexinergic innervation of POMC-containing neurons in the rat arcuate nucleus. NeuroReport 12:547-551.

Guan JL, Suzuki R, Funahashi H, Wang QP, Kageyama H, Uehara K, Yamada S, Tsurugano S, Shioda S (2002) Ultrastructural localization of orexin-1 receptor in pre- and post-synaptic neurons in the rat arcuate nucleus. Neurosci Lett 329:209-212.

Hara J, Beuckmann CT, Nambu T, Willie JT, Chemelli RM, Sinton CM, Sugiyama F, Yagami K, Goto K, Yanagisawa M, Sakurai T (2001) Genetic ablation of orexin neurons in mice results in narcolepsy, hypophagia, and obesity. Neuron 30:345-354.
Harris GC, Wimmer M, Aston-Jones G (2005) A role for lateral hypothalamic orexin neurons in reward seeking. Nature 437:556-559.

Kiyashchenko LI, Mileykovskiy BY, Maidment N, Lam HA, Wu MF, John J, Peever J, Siegel JM (2002) Release of hypocretin (orexin) during waking and sleep states. J Neurosci 22:5282-5286.

Lee MG, Hassani OK, Jones BE (2005) Discharge of identified orexin/hypocretin neurons across the sleep-waking cycle. J Neurosci 25:6716-6720.

Lin L, Faraco J, Li R, Kadotani H, Rogers W, Lin X, Qiu X, de Jong PJ, Nishino S, Mignot E (1999) The sleep disorder canine narcolepsy is caused by a mutation in the hypocretin (orexin) receptor 2 gene. Cell 98:365-376.

Mieda M, Williams SC, Sinton CM, Richardson JA, Sakurai T, Yanagisawa M (2004) Orexin neurons function in an efferent pathway of a foodentrainable circadian oscillator in eliciting food-anticipatory activity and wakefulness. J Neurosci 24:10493-10501.

Mileykovskiy BY, Kiyashchenko LI, Siegel JM (2005) Behavioral correlates of activity in identified hypocretin/orexin neurons. Neuron 46:787-798.

Muroya S, Funahashi H, Yamanaka A, Kohno D, Uramura K, Nambu T, Shibahara M, Kuramochi M, Takigawa M, Yanagisawa M, Sakurai T, Shioda S, Yada T (2004) Orexins (hypocretins) directly interact with neuropeptide $\mathrm{Y}, \mathrm{POMC}$ and glucose-responsive neurons to regulate $\mathrm{Ca} 2+$ signaling in a reciprocal manner to leptin: orexigenic neuronal pathways in the mediobasal hypothalamus. Eur J Neurosci 19:1524-1534.

Pinto S, Roseberry AG, Liu H, Diano S, Shanabrough M, Cai X, Friedman JM, Horvath TL (2004) Rapid rewiring of arcuate nucleus feeding circuits by leptin. Science 304:110-115.

Plum L, Ma X, Hampel B, Balthasar N, Coppari R, Munzberg H, Shanabrough M, Burdakov D, Rother E, Janoschek R, Alber J, Belgardt BF, Koch L, Seibler J, Schwenk F, Fekete C, Suzuki A, Mak TW, Krone W, Horvath TL, Ashcroft FM, Bruning JC (2006) Enhanced PIP(3) signaling in POMC neurons causes K(ATP) channel activation and leads to diet-sensitive obesity. J Clin Invest 116:1886-1901.

Sakurai T (2003) Orexin: a link between energy homeostasis and adaptive behaviour. Curr Opin Clin Nutr Metab Care 6:353-360.

Sakurai T, Amemiya A, Ishii M, Matsuzaki I, Chemelli RM, Tanaka H, Williams SC, Richardson JA, Kozlowski GP, Wilson S, Arch JR, Buckingham RE, Haynes AC, Carr SA, Annan RS, McNulty DE, Liu WS, Terrett JA, Elshourbagy NA, Bergsma DJ, et al. (1998) Orexins and orexin receptors: a family of hypothalamic neuropeptides and $G$ protein-coupled receptors that regulate feeding behavior. Cell 92:573-585.

Sakurai T, Nagata R, Yamanaka A, Kawamura H, Tsujino N, Muraki Y, Kageyama H, Kunita S, Takahashi S, Goto K, Koyama Y, Shioda S, Yanagisawa M (2005) Input of orexin/hypocretin neurons revealed by a genetically encoded tracer in mice. Neuron 46:297-308.

Schwartz MW, Woods SC, Porte Jr D, Seeley RJ, Baskin DG (2000) Central nervous system control of food intake. Nature 404:661-671.

Scott MM, Marcus JN, Elmquist JK (2006) Orexin neurons and the TASK of glucosensing. Neuron 50:665-667.

Suzuki R, Shimojima H, Funahashi H, Nakajo S, Yamada S, Guan JL, Tsurugano S, Uehara K, Takeyama Y, Kikuyama S, Shioda S (2002) Orexin-1 receptor immunoreactivity in chemically identified target neurons in the rat hypothalamus. Neurosci Lett 324:5-8.

van den Pol AN, Gao XB, Obrietan K, Kilduff TS, Belousov AB (1998) Presynaptic and postsynaptic actions and modulation of neuroendocrine neurons by a new hypothalamic peptide, hypocretin/orexin. JNeurosci 18:7962-7971.

van den Top M, Lee K, Whyment AD, Blanks AM, Spanswick D (2004) Orexigen-sensitive NPY/AgRP pacemaker neurons in the hypothalamic arcuate nucleus. Nat Neurosci 7:493-494.

Willie JT, Chemelli RM, Sinton CM, Yanagisawa M (2001) To eat or to sleep? Orexin in the regulation of feeding and wakefulness. Annu Rev Neurosci 24:429-458.

Willie JT, Chemelli RM, Sinton CM, Tokita S, Williams SC, Kisanuki YY, Marcus JN, Lee C, Elmquist JK, Kohlmeier KA, Leonard CS, Richardson JA, Hammer RE, Yanagisawa M (2003) Distinct narcolepsy syndromes in Orexin receptor-2 and Orexin null mice: molecular genetic dissection of Non-REM and REM sleep regulatory processes. Neuron 38:715-730.

Yamanaka A, Beuckmann CT, Willie JT, Hara J, Tsujino N, Mieda M, Tominaga M, Yagami K, Sugiyama F, Goto K, Yanagisawa M, Sakurai T (2003) Hypothalamic orexin neurons regulate arousal according to energy balance in mice. Neuron 38:701-713.

Yaswen L, Diehl N, Brennan MB, Hochgeschwender U (1999) Obesity in the mouse model of pro-opiomelanocortin deficiency responds to peripheral melanocortin. Nat Med 5:1066-1070. 